\title{
The Effect of the Project-Based Learning Model on Students' Resilience During the Pandemic Covid-19
}

\author{
Galih Dani Septiyan Rahayu ${ }^{1^{*}}$, Muhammad Rizal Fauzi ${ }^{2}$ \\ 1,2 Faculty of Education, IKIP Siliwangi, Cimahi, Indonesia \\ e-mail: galih040990@ikipsiliwangi.ac.id², fauzi@ikipsiliwangi.ac.id²
}

\begin{abstract}
This research is motivated by a change in the implementation of learning that is usually faceto-face in the classroom to learning through online due to the pandemic covid-19. Therefore this study was conducted aiming to analyze the effect of online-based project based learning learning model on the resilience of students during the pandemic Covid-19. The research method used was preexperimental with the design of one group pretest-posttest. The research population was consisting of four classes with a total of 183 students. While the sample used was only 92 students. The instruments used in this study were questionnaire instruments in accordance with indicators of resilience which were then processed statistically to answer the problem formulation in this study. The results of this study are the online-based project-based learning model that has a positive influence on student resilience while studying in the covid pandemic 19.
\end{abstract}

Keywords: project based learning, online learning, resilience, Covid pandemic 19

\section{Introduction}

COVID 19 is a global pandemic/epidemic that spreads in almost all countries in the world, including Indonesia. Based on data released from the World Health Organization (WHO), COVID 19 originated from the spread of inflammatory diseases that did not spread in Wuhan City since December 31, 2019 (Kemendagri, 2020; Xu et al., 2020). Indonesia is the fourth most populous country in the world, predicted to be more affected by the COVID 19 virus and in a relatively long period when compared to other less densely populated countries. When the SARS-CoV2 novel coronavirus hit China most severely during December 2019 - February 2020, Indonesia reported no cases of infection at all. Only on March 2, 2020, President Joko Widodo reported the first two cases of COVID-19 infection in Indonesia. On April 2, the country had reached 1790 arrested cases, 113 new cases, with 170 deaths, and 112 recoveries (Almarzooq et al., 2020; Djalante et al., 2020).

The spread of the COVID 19 virus in Indonesia basically through social activities such as crowding, shaking hands or other social activities involving physical contact, plus the lack of public awareness in maintaining health such as washing hands, exercising, resting sufficiently, and consuming nutritious food, through this the spread of COVID 19 virus is very massive because based on research delivered by the health ministry 1 person affected by the virus can potentially infect 3-4 people (Kemendagri, 2020). Therefore, since the adoption of the COVID pandemic 19 in Indonesia, the government has established health protocols that must be carried out by all people in Indonesia, especially those in the red zone of virus distribution, one of which is through social distancing, until now the implementation of the Large Scale Social Restrictions (LSSR). In line with government policy in limiting social activities, learning activities carried out in various educational institutions must be carried out online.

As one of the private tertiary institutions in Indonesia, IKIP Siliwangi carries out online learning following the advice of the ministry of education and culture. The process of learning change from usually facing to face on campus to being online as an effort to prevent the spread of COVID-19. This certainly becomes a new habit for students, thus requiring students to make adjustments to these changes. In addition to the process of adjusting for

\footnotetext{
${ }^{*}$ Corresponding author.

Received 23 July 2020; Accepted 12 September 2020; Available online 01 December 2020 (C) 2020 JPI. All Rights Reserved
} 
these changes, students are vulnerable to lectures in the first and second years still making adjustments to the learning system and learning culture in tertiary institutions that are different from education when in high school/vocational school, adjusting to the environment, adjusting to lifestyle, and students are required to deal with all this well (Gunarsa \& Gunarsa, 2008; Jamaluddin et al., 2020; Purwanto et al., 2020).

The object of this research is the fourth-semester PGSD IKIP Siliwangi students who take the Social Studies Elementary School course. Based on the results of the reflection questionnaire at the end of the third-semester lecture, the student still encountered various obstacles when adjusting the learning process, learning culture, and environment as well as the demands to adapt to online learning that was carried out this semester. The process of adaptation in the field of psychology is called resilience (Connor \& Davidson, 2003; Fernandes et al., 2018; Smith et al., 2008).

Resilience is one's ability to maintain psychological stability when experiencing difficulties, pressures, problems, and challenges so that they can rise up and adapt well to these things (Narendra \& Indriyani, 2018; Pidgeon et al., 2014; Uyun \& Rumiani, 2012). Resilience consists of seven indicators namely the ability to remain calm under stressful conditions called emotional regulation, the ability to control something that arises from within yourself such as desire, encouragement, joy, and pressure is called impulse control, the ability to believe that things can change for the better and have hope in the future and can control the direction of his life is called with optimism, the ability to analyze the causes of problems experienced accurately, ability to understand feelings, emotional conditions, and psychological conditions of others called empathy, individual confidence to be able to overcome the problems that might be experienced with his ability called self-efficacy; and the ability of individuals to interpret and obtain positive aspects after problems, pressures, or obstacles befall them (Reivich \& Shatté, 2002).

Research on student resilience in tertiary institutions has been carried out before such as research conducted by Astuti dan DS (2016) about the picture of first-level student resilience in terms of self-concept with the results of research that self-concept has a contribution to student resilience which means that the higher the self-concept then the higher the resilience. The second study conducted by (Prihartono et al., 2018) on the description of the resilience of first-year students in Padjajaran University nursing faculty, with the results of their research that the level of resilience of first-year students is in the low category, so it needs efforts to improve the quality of student adaptation. The third research is research conducted by (Cahyani \& Akmal,2017) about the spiritual role of resilience in students who are working on their thesis with the results of their research that is if students who work on thesis have a good spirituality including connection with oneself, connectedness with others or nature, and the connectedness of transcendent power (divinity), then it will help them to be able to face difficulties that occur during the thesis process.

Based on the following studies, it turns out that there has been no research related to the resilience of PGSD students and the use of learning models in an effort to increase student resilience, especially for students studying online at home during the COVID-19 emergency. Therefore, this research tries to apply an online project-based learning model in an effort to increase student resilience in the emergency situation of COVID-19. The choice of project-based learning model is because this model has student-centered and projectbased characteristics. Through the project-based learning model students are given more opportunities to explore abilities in cognitive, affective, and psychomotor aspects and students will have a product of their own work that will foster pride in themselves (Citradevi et al., 2017; Wicaksana, 2017).

In addition to this, the reason for choosing a project based learning model is based on the results of previous studies such as research conducted by (Guo \& Yang, 2012) with the title project based learning at university: teaching experiences of lecturers with research results namely learning in a higher education institution is defined as a process of active understanding and building up of meanings and skills, which fully complies with the essential ideas of project-based learning and research by (Roessingh \& Chambers, 2011) under the title project based learning and pedagogy in teacher preparation: staking out the theoretical 
mid-ground whose research results can be concluded that the project-based learning model that offers the principle of freedom for pragmatic and principled at the preparation of teachers at the undergraduate and postgraduate levels in the preparation of learning tools.

The learning steps of the project based learning model according to (Rahayu \& Samsudin, 2019; Johnson, 2014) consist of six steps starting from giving challenging statements to the evaluation process. The implementation of learning based on the steps of the project based learning model in this study are as follows provides a challenging statement, in this study the lecturer gives a challenging statement related to technological developments in the world of education which are increasingly sophisticated, so that requires teachers to be able to adapt and can utilize technology in learning, project planning, after students feel challenged by the statement that teachers must be able to adapt and be able to utilize technology in learning, then together students and lecturers make project plans which in this study the project is ICT-based teaching materials, the preparation of the project making schedule, the preparation of the project making schedule in this learning arranged together and agreed upon, supervise the preparation of the project, the supervision process is carried out every meeting until the project is completed through client by utilizing the Google classroom application, assessment of the resulting project, assessment of the project is carried out after the student project is completed with an assessment indicator that has been mutually agreed upon between the lecturer and the student, evaluation, at this stage students are given an evaluation with an observation sheet to measure the ability of students in compiling ICT-based teaching materials.

This study used a project-based learning model through online learning towards the resilience of the Siliwangi PGSD students during the emergency period of COVID-19. The results of the research are expected to be of benefit to students studying during the COVID19 emergency, parents of students, lecturers and universities, as well as other researchers who will study and develop student resilience, review and develop project-based learning models, and assess and develop learning during the emergency COVID-19.

\section{Method}

The research method used in this study is the pre-experimental research method. The reason for choosing the pre-experimental method is that the subjects used are students so that several factors can influence the results of the study such as student conditions, environmental conditions, learning conditions, and other unexpected things (Levy \& J. Ellis, 2011). The research design used is the one group pretest-posttest design to see the effectiveness of a treatment in the learning process that does not use comparison and is only done in one group. The brief design of the one-group pretest-posttest design is as shown in Table 1.

Table 1. One group pretest-posttest design

\begin{tabular}{ccc}
\hline Pretest & Treatment & Posttest \\
\hline $\mathrm{T}_{1}$ & $\mathrm{X}$ & $\mathrm{T}_{2}$ \\
\hline & & (Rahayu \& Nugraha, 2018)
\end{tabular}

Explanation of the steps of the research using one group pretest-posttest design by table 1 is as follows carry out the pretest (T1) to see the initial ability before being given treatment. In this study, the ability to question is student resilience, provide treatment $(X)$ which in this study is learning by using an online-based project-based learning model to increase student resilience, and carry out the posttest (T2) by looking at the final ability of the student resilience after being given treatment in the form of learning using an online-based project-based learning model.

This research procedure generally consists of three stages, namely the planning stage, the implementation phase, and the completion stage. The planning stage consists of an analysis of project based learning model learning, resilience analysis, determination of population and research samples, and preparation of research instruments. The 
implementation stage is the provision of treatment in the form of online-based project-based learning models for PGSD IKIP Siliwangi students who take social studies internship courses, taking data using instruments that have been prepared and validated, and data processing and analysis using SPSS. The last stage is the completion stage, which is concluding the results of research and findings during the research process.

The population in this study were all students of PGSD IKIP Siliwangi in the fourth semester who took social science internship courses consisting of four classes totaling 183 students. The sample in this study was determined directly without random and the sample was two classes of PGSD students totaling 92 students. The reason for choosing a random sample is not because of several fundamental reasons, namely the type of quasiexperimental research, facilitating the implementation of research, and the two classes sampled are two classes that have the same homogeneity.

The instrument used in this study was a questionnaire that was by the indicators of resilience. The selection of instruments was in the form of a questionnaire because the research process was carried out online-based so that the instrument considered appropriate, easy to use, and could produce accurate data was a questionnaire. The lift used previously tested validation to experts to retrieve accurate data. The data obtained were then processed statistically to see the effect of learning with an online-based project based learning model on the resilience of PGSD students during the COVID 19 emergency.

\section{Results and Discussion Result}

The results of this study can be seen in the results of the resilience questionnaire before being given assistance with the resilience questionnaire results after consultation. The results of the student resilience questionnaire before being taken shown in Table 2.

Table 2. The average pretest score is an indicator of PGSD student resilience

\begin{tabular}{llllllll}
\hline & \multicolumn{7}{c}{ Indicator } \\
\cline { 2 - 8 } Valid N & $\mathbf{1}$ & $\mathbf{2}$ & $\mathbf{3}$ & $\mathbf{4}$ & $\mathbf{5}$ & $\mathbf{6}$ & $\mathbf{7}$ \\
Missing & 0 & 92 & 92 & 92 & 92 & 92 & 92 \\
Mean & 2,12 & 0 & 0 & 0 & 0 & 0 & 0 \\
\hline
\end{tabular}

Based on Table 2 it can be concluded that from the seven indicators of student resilience, there are differences in the average value of each indicator. The highest indicator of the average value is the seventh indicator, namely the ability of individuals to interpret and obtain positive aspects after problems, pressures, and obstacles occur. The indicator that detected the lowest average value is the first indicator, namely the ability to remain calm in a stressed condition called emotional regulation. After the results of the questionnaire before being given treatment and analysis then the next is giving treatment in the form of learning with an online-based project based learning model for four meetings.

The results of student resilience questionnaire after being given treatment in the form of learning with an online-based project based learning model shown in Table 3.

Table 3. The average posttest score is an indicator of PGSD student resilience

\begin{tabular}{llllllll}
\hline & \multicolumn{7}{c}{ Indicator } \\
\cline { 2 - 8 } & $\mathbf{1}$ & $\mathbf{2}$ & $\mathbf{3}$ & $\mathbf{4}$ & $\mathbf{5}$ & $\mathbf{6}$ & $\mathbf{7}$ \\
\hline Valid N & 92 & 92 & 92 & 92 & 92 & 92 & 92 \\
Missing & 0 & 0 & 0 & 0 & 0 & 0 & 0 \\
Mean & 3,36 & 3,36 & 3,00 & 3,20 & 3,62 & 3,65 & 3,60 \\
\hline
\end{tabular}

Based on Table 3, after learning with the project based learning model there is an increase in the average value of each indicator of student resilience. The indicator with the 
highest average score is the sixth indicator, namely the individual's confidence to be able to overcome the problems that might be experienced with his ability called self-efficacy. While the indicator with the lowest average value is the third indicator, the ability to believe that things can change for the better and have hope in the future and can control the direction of life is called optimism. To see which indicators are significant improvements, the $\mathrm{N}$ gain test is performed. The results shown in Table 4.

Table 4. The average N-gain indicator of PGSD student resilience

\begin{tabular}{llllllll}
\hline & $\mathbf{7}$ & Indicator \\
\cline { 2 - 9 } & $\mathbf{1}$ & $\mathbf{2}$ & $\mathbf{3}$ & $\mathbf{4}$ & $\mathbf{5}$ & $\mathbf{6}$ & $\mathbf{7}$ \\
\hline N gain & 0,71 & 0,61 & 0,41 & 0,39 & 0,30 & 0,31 & 0,17 \\
\hline Kategori & High & Middle & Middle & Middle & Middle & Middle & Low \\
\hline
\end{tabular}

Based on Table 4, the indicator of student resilience that experienced the most significant improvement was the first indicator, namely the ability to remain calm in a stressed condition called emotional regulation with a Ngain value of 0.71 in the high category. But overall each indicator has increased after being given treatment in the form of online-based project based learning. Therefore, it can be concluded that learning with an online-based project based learning model provides a positive influence on the resilience of PGSD students during lectures during the covid pandemic 19.

\section{Discussion}

The learning process uses the online-based project-based learning model during the co-pandemic consisting of four meetings. From each meeting interesting findings were found. The findings at each meeting in detail are as follows.

Learning at the first meeting begins with a pretest which then continues with learning. Learning at the first meeting, the lecturer invites students to understand the material, needs, and problems associated with learning social science (IPS) in elementary schools today. After students understand these things, the lecturer invites students to make a project related to the needs and solutions to problems in social studies learning in elementary schools today. At this stage students look confused and shocked when invited to make a project. This happens because students follow new learning or are different from previous learning (Irwansyah et al., 2019; Macpherson, 2007; Syaputra et al., 2018).

This was an interesting finding and certainly improved at that time by explaining the importance of involving students and the benefits of learning by making a project that is useful for others. This is certainly not easy especially when learning is based online so that more motivation is needed such as showing the results of works that are in accordance with the project and its usefulness for others and simplification of the explanation of making the project. The selected project must also be considered not to make students burdened (Bernard et al., 2019; Guo \& Yang, 2012; Johnson, 2014). Projects made in learning in this study are project preparation of teaching materials in the form of media and ICT-based student worksheets such as the use of Ms. applications. Excel, Ms. Powerpoint, Scratch, quizziz, kahoot, VBA and other applications.

Learning at the second meeting of students has begun to determine what projects will be made per group and what projects will be made individually. At this meeting most students already looked quite optimistic that the project would be finished on time. An interesting finding at this meeting was that students were confused about sharing work with a group of friends considering learning was carried out online. The impact of this is that students want to group with close friends only and ignore friends who are not close friends (Dunlosky et al., 2013; Rahayu \& Arga, 2019; Subandi et al., 2019). To overcome this, the lecturer invites all students to understand the situation of their classmates. This is expected to build empathy in each student. After doing this, students finally understand the importance of grouping with students who are not close friends and have differences in various ways. 
Learning at the third meeting, student projects both group projects and individual projects have seen progress and at this meeting the lecturer invited students to explain the progress of their respective projects. At the time the students explained the project there were several groups who encountered obstacles while preparing their project. Barriers experienced by several students were noted and after all students explained the progress of the project the lecturer invited all students to jointly solve the obstacles and problems encountered by the students. This is in an effort to foster student resilience, especially indicators of emotional regulation, self-efficacy, and empathy in students (Pidgeon et al., 2014; Reivich \& Shatté, 2002). Of course this is not easy but with the packaging of learning and communication that is easily understood, most students are involved in this process (Mugara et al., 2019).

The fourth meeting is the last meeting in this study. At this meeting after learning students are given the same resilience questionnaire as before being given treatment. The findings at this meeting are that students have begun to calm down their projects, are optimistic that the project is useful for others, and can take the positive side of learning, making projects even though initially shocked, confused and less optimistic about completing the project because learning is carried out online through the covid pandemic 19 From this it can be concluded that student resilience does not depend on the complexity of the material being taught but the factor of lecturer creativity in packaging learning becomes more interesting, lecturer communication skills in delivering explanations, and student-centered learning also have an influence on student resilience even though learning is carried out online.

Based on the results of the student resilience questionnaire before and after carrying out online learning using the project-based learning model, there is a positive effect as described in the research results section. The general effect is that the PGSD student resilience is in a good category. Whereas when viewed from the respective indicators of resilience, each indicator has increased. When compared with the results of previous studies that have been stated at the beginning of the article, of course there is relevance especially to the research presented by (Astuti et al., 2016) regarding self-concept that affects student resilience. In this study, the project-based learning model has a positive effect on the formation of students' self-concepts. The results of this study provide the latest findings which in the results of previous studies put forward by (Cahyani \& Akmal, 2017) that spirituality has a positive influence on the resilience of the final students, it turns out that the communication and creativity of lecturers in learning are also able to have a positive influence on student resilience.

\section{Conclusion}

Findings during the study showed that the main factors influencing student resilience not only depend on the complexity of the learning topic and changes in the learning process from face to face to online due to the pandemic COVID 19, but the competence of lecturers such as packaging interesting learning processes with the selection of appropriate learning models, the use of technology information and communication in learning, and learning based on students in learning. In this study, although the online-based learning process during the pandemic COVID 19, it was packaged attractively and involved students more optimally by making a project both individual projects and group projects able to have a positive impact on student resilience. Therefore, the results of this study are expected to have implications for lecturers in developing their competencies, for lecturers who carry out the tri dharma of tertiary institutions during the COVID pandemic 19, and for the resilience of students who take part in the learning process during the pandemic COVID 19. It is expected that further studies can carry out studies with more complex models and broader subjects to create learning that can have a positive impact on student resilience 


\section{References}

Almarzooq, Z. I., Lopes, M., \& Kochar, A. (2020). Virtual learning during the COVID-19 pandemic. Journal of the American College of Cardiology, 75(20), 2635-2638. https://doi.org/10.1016/j.jacc.2020.04.015

Astuti, F., \& Ds, T. N. E. (2016). Resiliensi pada mahasiswa tahun pertama program kelas karyawan ditinjau dari konsep. Prosiding SEMNAS Penguatan Individu di Era Revolusi Informasi, 10.

Bernard, M., Sunaryo, A., Tusdia, H., Hendriani, E., Suhayi, A., Nurhidayah, Parida, M., Fauzi, A., \& Rolina, R. (2019). Enhance Learning Independence and Self Ability of Exceptional Children Through Developing Learning Media VBA for Excel Games. Journal of Physics: Conference Series, 1315, 012037. https://doi.org/10.1088/17426596/1315/1/012037

Cahyani, Y. E., \& Akmal, S. Z. (2017). Peranan spiritualitas terhadap resiliensi pada mahasiswa yang sedang mengerjakan skripsi. Psikoislamedia: Jurnal Psikologi, 2(1), 32. https://doi.org/10.22373/psikoislamedia.v2i1.1822

Citradevi, C. P., Widiyatmoko, A., \& Khusniati, M. (2017). The effectiveness of project based learning (PjBL) worksheet to improve science process skill for seven graders of junior high school in the topic of environmental pollution. Asking Questions, 6(3), 16771685.

Connor, K. M., \& Davidson, J. R. T. (2003). Development of a new resilience scale: The Connor-Davidson resilience scale (CD-RISC). Depression and Anxiety, 18(2), 76-82. https://doi.org/10.1002/da.10113

Djalante, R., Lassa, J., Setiamarga, D., Sudjatma, A., Indrawan, M., Haryanto, B., Mahfud, C., Sinapoy, M. S., Djalante, S., Rafliana, I., Gunawan, L. A., Surtiari, G. A. K., \& Warsilah, H. (2020). Review and analysis of current responses to COVID-19 in Indonesia: Period of January to March 2020. Progress in Disaster Science, 6, 100091. https://doi.org/10.1016/j.pdisas.2020.100091

Dunlosky, J., Rawson, K. A., Marsh, E. J., Nathan, M. J., \& Willingham, D. T. (2013). Improving Students' Learning With Effective Learning Techniques: Promising Directions From Cognitive and Educational Psychology. Psychological Science in the Public Interest, 14(1), 4-58. https://doi.org/10.1177/1529100612453266

Fernandes, G., Amaral, A., \& Varajão, J. (2018). Wagnild and Youngs's resilience scale validation for IS students. Procedia Computer Science, 138, 815-822. https://doi.org/10.1016/j.procs.2018.10.106

Gunarsa, S., \& Gunarsa, Y. (2008). Psikologi Praktis: Anak, Remaja, dan Keluarga. Gunung Mulia.

Guo, S., \& Yang, Y. (2012). Project-based learning: An effective approach to link teacher professional development and students learning. Journal of Educational Technology Development and Exchange, 5(2). https://doi.org/10.18785/jetde.0502.04

Irwansyah, F. S., Asyiah, E. N., \& Farida, I. (2019). Augmented reality-based media on molecular hybridization concepts learning. Tadris: Jurnal Keguruan Dan IImu Tarbiyah, 4(2), 227-236. https://doi.org/10.24042/tadris.v4i2.5239

Jamaluddin, D., Ratnasih, T., Gunawan, H., \& Paujiah, E. (2020). Pembelajaran daring masa pandemik covid-19 pada calon guru: Hambatan, solusi dan proyeksi. UIN Sunan Gunung Djati Bandung, 10.

Johnson, J. E. (2014). The Implementation of Project-Based Learning (PjBL) in an Earth Science Classroom: The Effectiveness of PjBL in Teaching Students about Sustainable Energy. The College at Brockport: State University of New York, 97.

Levy, Y., \& J. Ellis, T. (2011). A Guide for Novice Researchers on Experimental and QuasiExperimental Studies in Information Systems Research. Interdisciplinary Journal of Information, Knowledge, and Management, 6, 151-161. https://doi.org/10.28945/1373

Macpherson, A. (2007). Cooperative Learning Group Activities for College Courses. Kwantlen Polytechnic University, 205. 
Mugara, R., Rahayu, G. D. S., Arga, H. S. P., Muliadi, D. R., \& Risnawati, S. (2019). Penyusunan bahan ajar berbasis vlog dalam meningkatkan keterampilan komunikasi mahasiswa PGSD IKIP Siliwangi. P2M STKIP Siliwangi, 6(1), 63. https://doi.org/10.22460/p2m.v6i1p63-72.1253

Narendra, D. R., \& Indriyani, N. (2018). The Effect Of Five-Factor Model Ofpersonality And Religiosity Toward Adolescents's Resilience Whoose Parents Are Divorced. Jurnal Pengukuran Psikologi dan Pendidikan Indonesia (JP3I), 6(1). https://doi.org/10.15408/jp3i.v6i1.8149

Pidgeon, A. M., Rowe, N. F., Stapleton, P., Magyar, H. B., \& Lo, B. C. Y. (2014). Examining Characteristics of Resilience among University Students: An International Study. Open Journal of Social Sciences, 02(11), 14-22. https://doi.org/10.4236/jss.2014.211003

Prihartono, M. N., Sutini, T., \& Widianti, E. (2018). Gambaran resiliensi mahasiswa tahun pertama program A 2016 fakultas keperawatan Universitas Padjadjaran. 1, 9.

Purwanto, A., Pramono, R., Asbari, M., Santoso, P. B., Mayesti, L., Hyun, C. C., \& Putri, R. S. (2020). Studi eksploratif dampak pandemi covid-19 terhadap proses pembelajaran online di sekolah dasar. EduPchyCouns, 2(1).

Rahayu, G. D. S. (2019). Penerapan model project based learning dalam meningkatkan keterampilan penyusunan rencana pelaksanaan pembelajaran (rpp) mahasiswa PGSD IKIP Siliwangi. 6(2), 7.

Rahayu, G. D. S., \& Arga, H. S. P. (2019). Influence of VBA-based Monopoly Game in Microsoft Excel as Teaching Material on Primary School Students' Cross-Cultural Competence in Social Studies Learning. Mimbar Sekolah Dasar, 6(2), 147. https://doi.org/10.17509/mimbar-sd.v6i2.16935

Rahayu, G. D. S., \& Nugraha, F. F. (2018). Effect of cooperative learning model type team game tournament (tgt) on cross-cultural skills in learning science social knowledge in primary school. PrimaryEdu - Journal of Primary Education, 2(1), 63. https://doi.org/10.22460/pej.v1i1.671

Reivich, K., \& Shatté, A. (2002). The resilience factor: 7 essential skills for overcoming life's inevitable obstacles. Broadway Books.

Roessingh, H., \& Chambers, W. (2011). Project-based learning and pedagogy in teacher preparation: Staking out the theoretical mid-ground. International Journal of Teaching and Learning in Higher Education, 23(1), 12.

Smith, B. W., Dalen, J., Wiggins, K., Tooley, E., Christopher, P., \& Bernard, J. (2008). The brief resilience scale: Assessing the ability to bounce back. International Journal of Behavioral Medicine, 15(3), 194-200. https://doi.org/10.1080/10705500802222972

Subandi, S., Fauzan, A., Afriyadi, M. M., \& Ramli, M. (2019). Implementation of multicultural and moderate Islamic education at the elementary schools in shaping the nationalism. Tadris: Jurnal Keguruan Dan IImu Tarbiyah, 4(2), 247-255. https://doi.org/10.24042/tadris.v4i2.5003

Syaputra, E., Sariyatun, S., \& Sunardi, S. (2018). The Strategy of Enhancing Student's Social Awareness through History Learning Based on Selimbur Caye Oral Tradition Values. International Journal of Multicultural and Multireligious Understanding, 5(4), 22. https://doi.org/10.18415/ijmmu.v5i4.161

Tim Kerja Kemendagri. (2020). Pedoman Umum Menghadapi Pandemi Covid -19 Bagi Pemerintah Daerah. Kementrian Dalam Negeri.

Uyun, Q., \& Rumiani, R. (2012). Sabar dan shalat sebagai model untuk meningkatkan resiliensi di daerah bencana, Yogyakarta. Jurnal Intervensi Psikologi (JIP), 4(2), 253276. https://doi.org/10.20885/intervensipsikologi.vol4.iss2.art7

Wicaksana, E. J. (2017). The effectiveness of project based learning model to improve students vocational skills. 6(3), 1694-1699.

Xu, X., Han, M., Li, T., Sun, W., Wang, D., Fu, B., Zhou, Y., Zheng, X., Yang, Y., Li, X., Zhang, X., Pan, A., \& Wei, H. (2020). Effective treatment of severe COVID-19 patients with tocilizumab. Proceedings of the National Academy of Sciences, 117(20), 10970-10975. https://doi.org/10.1073/pnas.2005615117 